\title{
Relational networks of knowledge production in transnational law firms
}

\author{
James R Faulconbridge* \\ Department of Geography, \\ Lancaster University, \\ Lancaster, \\ LA1 4YW \\ U.K. \\ Email for correspondence: j.faulconbridge@lancaster.ac.uk \\ Telephone: +44 (0)1524592203 \\ Fax: +44 (0)1524 847099
}

* Corresponding Author

Forthcoming in Geoforum 


\title{
Relational networks of knowledge production in transnational law firms
}

\begin{abstract}
For geographers, debates surrounding the knowledge economy have reinvigorated interest in the geographies of learning and knowledge production. Particularly topical are discussions of the possibility of spatially stretched (global) learning, something especially relevant to professional service firms where the production and management of knowledge across transnational organizational networks is essential. Taking this as its starting point, the paper explores the way knowledge is produced and circulated in transnational legal professional service firms. Drawing on the ideas of relational economic geography to analyse original empirical material, it highlights the way relational networks are socially constructed to allow learning to be stretched across space. The paper then goes on to identify the 'politics' of inclusion in these networks and the exclusivity of membership. It also highlights the geographies of power that influence the nature and affect of the knowledge produced and circulated. It does this by examining the role of relational knowledge networks in the 'Americanization' of legal practice in Europe and the impacts of such changes on national institutional and regulatory contexts. It is, therefore, argued that transnational corporate networks need to be viewed as heterogeneous and 'embedded spaces of social practice'. It is shown that studying the actors and their interactions across relational networks is vital to fully understand how global relational forms are constructed and to understand their structuring effects on the global economy.
\end{abstract}

\section{Keywords:}

Knowledge; professional service firms; law; globalization; relational networks; London; New York; interviews 


\section{Relational networks of knowledge production in transnational law firms}

\section{1) Introduction}

Debate surrounding the 'knowledge economy' (Department for Trade and Industry, 1998; Leadbeater, 1999; OECD, 2000) has highlighted the importance of strategies to effectively create, manipulate and exploit knowledge within firms in order to drive competitiveness. For geographers, this has renewed the urgency of deliberations about the socio-spatial characteristics of learning and knowledge (Amin and Cohendet, 1999; 2004; Bunnel and Coe, 2001). For example, studies of manufacturing (Sturgeon, 2003), advertising services (Faulconbridge, 2006; Grabher, 2002) and retail (Currah and Wrigley, 2004) have identified the importance of globally stretched practices of knowledge production and circulation. This also links to wider discussions within the social sciences of knowledge management in organizations (e.g. Skymre, 1999). Focus here is upon the way firms implement practices that, crudely defined, allow employees to learn from one-another's insights and to translate and reinterpret the knowledge of colleagues.

Exploration of such issues by geographers has been grounded in several recent theoretical developments. Attempts within economic geography to 'open the black box' used to represent firms (Taylor and Asheim, 2001) have revealed the socially and culturally inflected networks that influence decision making, 
efficiency and productivity in firms (Schohenberger, 1997). Analyses of 'relational economic geographies' (Boggs and Rantisi, 2004; Bathelt and Glucker, 2003) and 'global production networks' (Dicken et al. 2001; Henderson et al. 2002) have also provided more delicate conceptualisations of the spatial characteristics of global organizational networks. Such approaches take into account both the role of socially constructed network spaces and their cultural and political inflection (Dicken et al. 2001). It has, therefore, been suggested that we trace the relational actor-networks involved in the constitution of space and time in order to identify the practices of network formation and their time-space heterogeneity (Hess, 2004). Amin $(2002,386)$ has argued that there is the need for "a different interpretation, one which emphasises a topology marked by overlapping near - far relations and organisational connections that are not reducible to scalar spaces".

To date, however, there has been a failure to use empirical material to develop such an approach. Equally troubling is the relative neglect of service industries by geographers in their analysis of relational networks (but see Coe et al. 2005; Currah and Wrigley, 2004) and, in particular, knowledge-intensive or professional service firms (PSFs). As Morris and Empson $(1998,612)$ note, "[t]he knowledge base represents both an input and an output of the PSF. It is an input in terms of the expertise residing in the firm and it is an output in the form of products or services generated to solve client problems". Consequently, Lowendahl $(2000,152-153)$ proposes that "global presence may enable the firm to develop broader 'experience records' and shared knowledge...In PSFs the 
competitive advantage, if achieved, results from the ability of the firm to continuously tap into the knowledge developed in all relevant centres of the world".

This paper, therefore, offers a timely empirical analysis of the way transnational legal PSFs develop relational networks of knowledge production. Transnational law firms provide an ideal case study to examine issues related to the geographies of knowledge production. Their primary aim is to deliver integrated services to clients through the synergism of the knowledge of lawyers working in several offices. As one firm suggests, "Our knowledge, like our clients' interests, transcends geographic boundaries. All of our clients have access to the expertise of our lawyers, wherever they are based. As a single partnership, White \& Case functions as an integrated team" (http://www.whitecase.com/About/Overview.aspx [accessed 12/01/06]). Consequently, successful engagement in forms of stretched knowledge 'management' is essential but also inevitably raises a number of significant challenges. As Beaverstock et al. (1999) suggest, transnational law firms are simultaneously embedded, to use Hess' (2004) terminology, by the national 'territorial' systems of law and the transnational network relationships between offices and between offices and TNC clients. This means that the simplistic transfer of legal best practice between offices is impossible. However, effectively nurtured transnational networks might allow the dis- and re-embedding of legal practices. Thus studying transnational law firms and exploring the ways learning networks are achieved as social spaces might advance our understanding of the 
characteristics and formation of relational networks. Even more significantly, this might also reveal the way transnational networks are beginning to influence the legal and professional systems and practices in which each office is embedded as ideas, norms and values get retranslated into the local context, thus influencing existing national practice in ways unlikely before such extra-local influences existed. Indeed, studying this peculiar local-global tension in the organization of transnational law firms allows two arguments to be put forward that have significance for wider debates about relationality.

First, the empirical material is used to show that unpacking the social constitution of relational network space is essential as we further strive to develop understanding of relational economic geographies. This is exemplified by the way law firms rely upon the nurturing of spaces of social practice to enable stretched knowledge production, something which points to the need for microlevel analyses that bring into view the actors in relational networks. Second, it is suggested that the nature of such networks leads to complex power relations, something often obscured by macro-level analyses of the outcomes of relationality. The empirical material is, therefore, used to embellish the work of geographers, and especially Allen (2003), on power as a relational construct. This again highlights the value of focussing upon the human and non-human, social and organizational actors and influences in relational networks and the ordering outcomes of powerful relations. The value of such an approach is exemplified by exploring the emergence of a 'transnational' legal model based on US principles and the way spheres of influence that were previously national - 
legal practice and the norms of lawyer's behaviour - are being tainted and manipulated by extra-local, transnational forces.

The rest of the paper develops these arguments over five further sections. Section two explores the ways that extant literatures can inform our understanding of transnational knowledge networks in legal PSFs. Section three outlines the methodology used to collect the empirical interview data analysed in the paper. Sections four and five then present an analysis of the empirical material that highlights the relational architectures of knowledge production, their social constitution and embeddedness, and the power relations in these networks. Section six offers some conclusions that indicate the significance of these findings. The need for fine-grained analysis of the social practices and on goings in relational networks is highlighted as well as the importance of focussing upon the conditioning effects of power relations in relational networks on the structuring of economic activities.

\section{2) Conceptualising relational knowledge networks in legal PSFs}

Geographers have long been interested in producer services (Daniels, 1993) and most recently have endeavoured to analyse the organizational forms of global firms. Extant studies (Beaverstock et al. 1999; Warf, 2001) provide important foundations for our understanding of transnational legal PSFs, in particular highlighting the dominance of US and UK corporate law firms ${ }^{1}$.

\footnotetext{
${ }^{1}$ Beaverstock et al. (1999) note that global legal PSFs operate using one of three models: (a) The 'global firm' where offices are opened overseas, managed and controlled by the partnership; (b)
} 
However, these studies fail to provide analysis of the ways such transnational forms are constructed. As Jones' (2005, 179, original emphasis) reminds us, there is a pressing need to focus upon the "practices of transnational business (which explodes the firms as a black-box concept) rather than the quantifiable measures of the outcomes of global business activity". Solice can be partially found in the work of Beaverstock (2004) who illustrates the important role of expatriation as a transnational business practice allowing knowledge circulation. However, beyond this we are forced to turn to studies of other industries such as retail (Currah and Wrigley, 2004) or more generic examinations of the global geographies of innovation (Bunnel and Coe, 2001) and the global architectures of knowledge (Amin and Cohendet, 2004) in order to glean understanding of the nature of stretched practices of learning. This is not to say these studies are not instructive as to how legal PSFs might engage in global knowledge management. For example they all agree upon the importance of:

- Analysing the construction of 'spaces of interconnection' in global organizations (Amin and Cohendet, 2004; Bunnell and Coe, 2001).

'Best friends', alliance networks, where overseas offices are controlled by local partnerships but integrated to form a global network operating under one name; and (c) membership of global legal associations where every firm is independent and members call on one-another to assist with cross-border transactions. All of the firms studied here use the 'global firm' strategy. In 'alliance networks' and 'global legal associations' knowledge management and leverage is more difficult and less common as each office operates as a relatively independent unit. 
- Understanding the social constitution of the 'transnational communities of practice' that form 'social spaces of learning' (Morgan, 2001).

- Deconstructing the troublesome local-tacit/global-explicit dichotomy (Allen, 2002).

It is, therefore, possible to draw upon and develop these ideas to analyse the relational knowledge production networks in transnational legal PSFs. However, a number of further points need to be considered to both fully explain the constitution of the networks that produce competitive advantage through global relational interdependency and their specific characteristics in transnational law firms.

\section{1) Architectures of knowledge production in global organizations}

Studies of strategic organizational forms (Nohria and Ghoshal, 1997) have, most recently, suggested that the transnational organizational architecture is most valuable because of its ability to create a matrix of knowledge interconnections. First proposed by Bartlett and Ghoshal (1998), transnationalism allows 'knowledge diffusion and development worldwide' by integrating and connecting all parts of a global firm's network, thus allowing the synergism of ideas, insights and experiences. Bunnell and Coe $(2001,570)$ therefore argue that effective innovation "involve[s] a complex and evolving integration, at different levels, of local, national and global factors [not] 
exclusively at one particular scale but instead across various spatial scales simultaneously".

Central to such studies have been examinations of the role of various forms of 'transnational community' (Amin and Cohendet, 2004; Bunnel and Coe, 2001; Faulconbridge, 2006; Morgan, 2001; Wenger et al. 2000). This work illuminates two related issues. First, the modes of interconnectivity that allows community members to communicate. Here the rise of, and improvements in, information and communications technologies have been noted and their ability to support the construction of the communities that allow knowledge production and circulation. Technologies ranging from the telephone to the Internet and videoconferencing mean that knowledge production "includes, yes, face-to-face meetings, sociality, and casual contact...but it also draws on distant objects such as drawings faxed between offices around the world, global travel to form temporary project teams, and daily internet/telephone/video conversations" (Amin and Cohendet, 2004,110). Grabher's (2002) work on project team architectures in PSFs reinforces this view, highlighting in particular the value of consolidated inter-personal networks for organizational learning.

Second, studies have also highlighted the composition of transnational communities and the forces binding members together and allowing learning to be stretched across space. In particular, the vital gelling agent for such communities has been shown to be shared domains of interest emerging from shared work and professional practices. Wenger et al. $(2000,25)$ note that "[w]hat allows members to share knowledge is not the choice of a specific form of 
communication (face-to-face as opposed to Web-based, for instance) but the existence of a shared practice - a common set of situations, problems and perspectives". Consequently, the spatial distribution of communities becomes irrelevant. Instead, shared practice ties communities together and creates a form of relational proximity that ensures learning is successful (Blanc and Sierra, 1999).

These approaches are useful in understanding the way transnational law firms organise because of the need for cooperation and collaboration between lawyers in different offices throughout the world. One of the principal aims of transnational law firms is to develop transnational structures for corporate activities, e.g. a framework that allows the merger of two firms originating in different countries. In order to do this, lawyers in several offices work together in 'project teams' (Grabher, 2002). As one firm's promotional literatures argue, "Working together as one firm means we: all take responsibility for, identify with, and share in the success of, $A \& O$; ensure a good team spirit, openness and friendliness in the workplace; make it fun to work at, and with, A\&O; help support each other and take pride in each other's success; put the interests of $A \& O$ ahead of any individual or group within it“" (http://www.allenovery.com/asp/general.asp?pageid=1926\&languageid=0 [accessed 12/02/2006]).

Of course, it is always important to be critical of such corporate rhetoric. The empirical material presented in the second half of this paper, therefore, allows the nuances of such team-working to be unpacked in more detail. It also 
fills the current void in research providing a micro-scale view of the type of relationships involved in such transnational communities, the practices involved in collaboration and the socio-political influences on this process. As noted above, literatures have been quick to note the existence of such communities and their modes of operation (e.g. the use of email, telephone etc.). However, little attention has been paid to the intricacies of their construction and the fine grained and ongoing social complexities of these transnational communities. Unpacking this is essential if we are to develop analyses of the construction of time and space through social practice that others have proposed (e.g. Amin, 2002).

\section{2) Embedded and relational geographies}

As noted above, the turn in economic geography towards a relational analysis of global organizations also provides a useful conceptual backdrop against which to explore the spaces of social action making up relational knowledge networks (Bathelt and Glucker, 2003; Boggs and Rantisi, 2003; Peck and Yeung, 2003). Such work points to how "[f]irms... become circulatory networks...flow and mobility are increasingly assumed into the system, with elaborate schemes in place to ensure the rapid transfer of people, goods, money and information around the world" (Amin, 2002, 394). Consequently, we must look at the human actors in detail and their practices that enable such circulatory spaces to emerge so as to avoid "descend[ing] into a mechanistic 
framework... without a sense of the social processes that constitute these relationships" (Dicken et al. 2001, 105).

It has also been cautioned, however, that as part of meeting this challenge there must be exploration of the economic, cultural, political and social constitution and inflection of relational networks. Yeung $(2004,38)$ argues there is a need to explore their 'relational geometries' to understand "the spatial configurations of heterogeneous relations among actors and structures through which power and identities are played out and become efficacious". Hess (2004) attempts to deal with this challenge by treating the sociological concept of embeddedness as processual in character and exploring the ways social relationships between economic actors are influenced by embedded economic forms. Utilising the concept of the 'rhizome', Hess $(2004,179-180)$ proposes that relational network processes are affected in an ongoing and contested fashion by forms of social, cultural, political and economic inflection that affect both interactions in and outcomes of relational network economies.

It seems, then, that a tri-part analysis is needed. First, of the practices involved in 'producing' relational connectivity. Second, of the heterogeneous nature of the actors and their interactions in relational networks. This requires us to recognise the contingent and continuous (re)production of meaning in relational networks. And, third, of the outcomes and ordering effects of the relational forms that emerge. Law firms provide an ideal case study to put such a tri-part analysis into practice. Economic value is created in transnational law firms, and transnational legal services are only possible, when complex webs of 
social relations are established between lawyers in different parts of the World.

Exploring the makeup of the relational networks that facilitate this business model is likely to further demystify the practices involved in, and the influences upon, network formation and the complex relational geometries involved. Of course, to do this requires an explanation grounded in an understanding of the contemporary context of the legal industry, something that further emphasises the importance of not only analysing the form of relational networks but also their wider role in the structuring of the global economy.

\section{3) Relational networks and the (re)production of legal practices}

A key issue highlighted by studies of the sociology of the legal profession has been the affect of globalization on the organization of law firms and professional practice (e.g. Brock et al, 1999; The Economist, 1996). In particular, it has been suggested that this has led to a form of 'Americanization' whereby US, and more recently UK firms dominate most cross-border corporate legal work and influence the nature and culture of such legal practice. As Trubek et al. $(1994,420)$ argue, there is a need to tell the "story of the growing dominance of a particular mode of production of law which began in the United States" (Trubek et al. 1994, 420).

The leading transnational law firms (table 1) and their organizational characteristics are the result of the development, during the mid part of the twentieth century, of a form of legal practice that is often referred to as 'Cravathism' and 'mega-lawyering' (Trubek et al. 1994; Spar, 1997). Under such 
a schema, lawyers provide commercially sensitive advice to clients that is designed to provide positive business outcomes. In particular, it means avoiding posturing about legal positionalities and academic-style debates about legislation. Instead, focus is placed upon finding the most effective way to apply, and operate within the law so as to meet the client's commercial needs ${ }^{2}$.

[Insert table 1 here]

After emerging in the USA and particularly in New York's law firms (Smigel, 1965), such a system quickly spread to the UK as globalizing US and increasingly UK clients demanded such commercially orientated legal advice ${ }^{3}$. The Economist (1996) suggested US and UK transnational legal PSFs 'wrapped red tape around the World' and effectively created a captive market for corporate legal services, a market based on the principles of the Cravath, mega-law, approach. In stark contrast, many other civil law European jurisdictions (e.g.

\footnotetext{
${ }^{2}$ Four key characteristics that differentiate 'mega-law' firms from their counterparts can be identified based on the work of Flood (1996): (a) the increased size of firms; (b) specialisation in areas of corporate law and serving large corporate clients; (c) high levels of internal coordination; and (d) the increasing use of partner review and remuneration based on financial measures of performance.

${ }^{3}$ The driving force behind the increase in demand for commercially sensitive legal services in the UK was, in particular, the growth in number of American law firms in the City of London and the increased awareness of clients of the benefits of a 'mega-law' service.
} 
France, Germany and Italy) have been slower to adapt to mega-lawyering practices (MacDonald, 1995).

Where it has and continues to occur, the propagation in transnational legal PSFs of 'mega-lawyering' practices can only be understood by examining the organizational structures of the law firms involved and the way they facilitate the circulation of the knowledge and ideas 'mega-lawyering' is based upon (Nelson and Trubek, 1992). As Flood $(1995,160)$ suggests, "it may be preferable to talk of the export of American techniques that are adapted to local cultures and become local knowledge". This highlights the importance of fully understanding the character of the relational networks transnational law firms develop and, importantly, the potential power of such structures. Even in the more beaurocratically managed professional businesses it is "networking and corporate culture [that] ensure[s] the integration of activities" (Ferner et al. 2001, 343). Consequently, in the context of this paper, the ways such networking and propagation of culture is tied up with global knowledge production and circulation is particularly significant.

The paper, therefore, draws on the frameworks outlined in this section to analyse empirical material exploring the way transnational legal PSFs operating in London and New York engage in 'knowledge diffusion and development worldwide ${ }^{4}$. Specifically, it investigates: the way relational networks are

\footnotetext{
${ }^{4}$ The London and New York offices were chosen as: (a) they are the dominant, home-country, offices of global law firms; and (b) UK and New York State law dominates cross-border corporate legal work in the emerging transnational legal domain (Trubek et al. 1994).
} 
constructed in these firms; the way these networks operate as social and cultural constructions; and the affects on the way transnational firms produce and manage knowledge worldwide on different national legal systems. This reveals the importance of focussing upon the actors and the social practices involved in producing such relational network space and also the ordering capability of relational networks in terms of their effect on the spread of such (American) mega-law practices.

\section{3) Methodology}

The empirical material analysed in this paper was collected through 29 semi-structured interviews conducted between September 2003 and June 2004. Interviewees held various positions in transnational legal PSFs operating in London and New York ranging from associate (the most junior rank) to managing partner (the most senior rank). The lawyers interviewed had between six and thirty years experience (fifteen years on average) and had worked for between one and four firms (two on average). All specialised in either corporate or finance law.

Individuals were selected using the following strategy. Company web sites of the top twenty 'transnational' firms, ranked by number of offices, were consulted and three individuals contacted in each firm (60 in total). First, the managing partner. Second, a partner from either the corporate or finance practice area, the dominant focus of lawyers' work in cities such as London and New York. Third, an associate lawyer in the corporate or finance practice group. 
The corporate/finance partners and associates were selected at random using a sampling strategy. Most firms list lawyers on their websites in alphabetical order by office. By consulting lists of lawyers for the London and New York offices of each firm a random sample was produced by contacting the first listed corporate or finance partner or associate. Following this process (which resulted in 23 interviewees being completed, a 38\% acceptance rate), a further six lawyers were recruited using the 'snowballing' approach. Interviewees often recommended meeting with other individuals in the firm - for example, those lawyers involved in knowledge management activities - and, where possible, these contacts were followed up. In total, at least one lawyer was interviewed in 11 out of the top 20 firms $^{5}$. At the time of completing interview these firms had between 11 and 69 offices worldwide, employed between 573 and 3,053 lawyers and had global revenues of between $£ 174 \mathrm{~m}$ and £950m (The Lawyer, 2004).

An interview schedule was used that explored the practices involved in learning and knowledge management in transnational law firms. Following the logic of 'new economic geography' (Yeung, 2003), the intention was to let interviewees 'speak for themselves' and openly describe the practices and processes relevant to the issues being researched. As the interviews formed part of a wider project, interviewees were asked to describe all the 'spaces' in which learning or knowledge management activities took place. The responses of interviewees generally led to discussions of practices within three main

\footnotetext{
${ }^{5}$ There was no trend in terms of the size, country of origin or any other factor in the firms where no lawyers were interviewed.
} 
spaces: (a) the offices of the firm they worked for; (b) the city spaces they worked in and the various arenas of learning within these cities; and (c) the transnational corporate networks of the firms they worked for. In each case interviewees were probed about the situations in which learning occurred, what affected whether it occurred, the influences and limits on the success of learning and the benefit gained from the enactment of learning practices within each space. Where practical, 'validation' questions (Schoenburger, 1991) were inserted into the interview schedule in an attempt to identify and filter-out corporate rhetoric that could potentially cloud the picture presented ${ }^{6}$. By the end of the process, the researcher felt 'theoretical saturation' had been achieved as the same themes and ideas were repeatedly emerging with limited amounts of novel data (Glaser and Strauss, 1967). By interviewing individuals in various positions of authority it was possible to include multiple voices and perspectives. Only discussions relating to space (c) are reported here with other findings reported elsewhere (Faulconbridge, 2007, forthcoming).

Interviews lasted between 40 and 90 minutes (55 minutes on average) and were tape recorded. Quotes representing key issues and ideas were then extracted from the transcripts produced using the logic of grounded theory (Glaser and Strauss, 1967). This involved a recursive process that initially highlighted key themes in the empirical data and then coded transcripts

\footnotetext{
${ }^{6}$ Schoenburger (1991) suggests 'validation questions' are questions used to address a topic covered earlier in the interview but from a different perspective. This allows the researcher to cross-verify the responses and ideas presented to check for inconsistencies and responses aimed to mislead.
} 
appropriately. Quotes, both supporting and contradicting the main arguments were then used to tease out the processes, practices and socio-political influences upon the learning process ${ }^{7}$. To maintain the anonymity of interviewees only interviewee number is provided in this analysis. Where relevant, the position of the interviewee within the firm is also identified.

\section{4) Transnational learning and organizational networks in legal PSFs}

At one level, it is entirely possible that transnational law firms could operate without tight relational couplings. For example, legal networks such as The Interlex Group simply act as transnational structures through which lawyers can 'buy' the services of an overseas lawyer as and when needed ${ }^{8}$. However, an

\footnotetext{
${ }^{7}$ Inevitably, as with all elite research, it is important to remain critical of the views presented. Data is always potentially contaminated and partial because of attempts by interviewees to retain a degree of power in the interview relationship, maintain an image or protect the firm they work for (Schoenburger, 1991; Herod, 1999). Overall, however, the repetitiveness of the ideas presented in this paper would indicate the issues discussed are indicative of on goings within the firms studied. It has been attempted to represent the voices of everyone interviewed, in particular in terms of differences in opinion depending on level of seniority in the firm. Inevitably, it is impossible to represent every contradiction appearing in the interview data. However, where contradictions repeatedly emerged they are discussed in the analysis.

${ }^{8}$ Interlex is an association of law firms located in cities throughout the World. Its members specialise in providing legal services to firms outside of their home country. However, the group is not a joint venture or merger of any type. Each firm is independent and Interlex simply acts as an efficient referral network whereby a law firm can locate a service provider in an overseas
} 
important rationale and benefit of being a truly global organization, as all the firms in table 1 are, is the advantage gained from tightly coupled, established and ongoing relational ties between lawyers in different offices. These allow learning with and from overseas colleagues in a way that creates competitive advantage and improves the effectiveness of the services provided to clients. As two interviewees described the way they engaged in globally stretched knowledge production and circulation:

"Often there are particular factors, particular approaches, that have been used in another jurisdiction which have not been used in this particular jurisdiction but are easily transportable. And the way you get that is you talk through your problem with fellow partners in other jurisdictions, draw on their experience and suggestions and feed that in" (4).

"So, you might have a lawyer whose done certain types of work, they speak to another lawyer whose done a certain types of work, and between them by talking things through, by sharing their experiences they actually work out something innovative...So when you're up against a problem, first you walk down the corridor and talk to your colleagues, but if they can't find a solution, and you think there is more mileage to be had out of this, you pick up the phone and talk to the partners who you think might have something to offer here, and they might be in Germany, in New York, or in France" (9).

country in which they do not have an office. There is no attempt to integrate the firms or develop ongoing relationships of any kind. 
These quotes provide a number of insights. First, they reveal that lawyers in globally integrated firms use their relational networks to benefit from knowledge production and circulation (i.e. developing new understanding based on the synergism of experiences and ideas and passing on extant knowledge so that it can be adopted, adapted and reconstituted by overseas colleagues). Second, the quotes indicate that creating the architectures (Amin and Cohendet, 1999) and networks (Skymre, 1999) that facilitate this knowledge production and circulation process is critical. In particular, they reveal that it is the way individuals within global organizations construct and benefit from various interpersonal relationships with colleagues that ensure intra-organizational learning occurs. These relationships are often supported by non-human actors such as emails, documents detailing case study transactions or innovations in legal practice, and reference to professional publications such as The Lawyer and The Law Gazette. Reading such documents helps establish a common-base for understanding and, for the case studies written by colleagues within the firm, helps develop understanding of a colleague's past experience and approach to legal problems. However, as one interviewee noted:

"...it [reading things] will never replace giving the guy a ring and saying 'what's the counsel you can offer?' And it's quite interesting when they write up the knowledge and learning's, inevitably these things are interesting but pretty vanilla, the lumps and bumps are taken out of everything when a report or review is written. And you only get the lumps and bumps or the local colour as it were by actually talking to people. So actually building up a network of contacts is your life saver" (23). 
Interviewees were, therefore, further interrogated about the ways these allimportant interpersonal networks are formed, embedded and used so as to create time and space through which knowledge and its production can be stretched.

\section{1) Relational network forming practices}

The networks that allow knowledge production and circulation result from individuals developing awareness of, and relationships with colleagues who have expertise and knowledge relevant to one specialist area of legal practice. Lawyers in transnational corporate law firms specialise in both legal practice areas (e.g. antitrust/competition; banking and finance; $M \& A /$ corporate; tax) and industry domains (e.g. airlines; financial institutions; real estate). It is essential that they know the other lawyers in the firm who specialise in their practice and industry areas. In the law firms studied, this awareness emerged in two ways. First, transactional encounters, when individuals from several offices work together on a cross-border project involving several legal jurisdictions. Second, non-transactional encounters such as telephone calls resulting from the deliberative searching of an 'expertise database'9. Grabher (2002) refers to this as 'know-who' knowledge and highlights a similar process in advertising PSFs.

Table 2 provides several quotes that exemplify this process in more detail. As it makes clear, cultivating such relationships is central to creating spaces in

\footnotetext{
${ }^{9}$ Expertise databases existed in all of the firms studied. They list individuals working for the firm and their practice and industry speciality as well as past transactional experience.
} 
which stretched learning can take place. Inevitably, the geography of these network spaces reflects the spatially patchy networks of transnational legal PSFs (Beaverstock et al. 1999). However, as figure 1 suggests, despite the significance of South East Asia in the activities of transnational law firms, interpersonal networks stretched principally between: the London and New York offices; and the London, New York and continental European offices. It was somewhat surprising that the South East Asian offices of these firms were not as intensely tied into knowledge production and circulation in the same was as the North American, UK and Western European offices. This was the unavoidable consequence, however, of the failure to construct the type of relational spaces between these and other offices. A number of factors seem responsible for this and are discussed more fully later in the paper. The important point is that figure 1 clearly highlights the need to produce space in global organizations through the social practices of key actors.

[Insert table 2 here]

[Insert figure 1 here]

\section{2) Embedded relational knowledge networks}

Figure 1 also shows that it is important to recognise qualitative differences in the nature and form of the relational networks between different offices. For example, it suggests that the relationships between the New York and Eastern 
European offices are 'weaker' than those between New York and Western European offices. This point deserves further examination, something that requires an understanding of the role of embeddedness in relational networks. In particular, the emergence of what Hess (2004) refers to as 'transnational embeddedness' is important whereby ongoing stretched social practices produce socio-economic conditions that mediate effective relational action.

The empirical material revealed that, while the establishment of the networks that allow global knowledge production and circulation is essential, this was only half of the story. To begin, the effectiveness of these networks was suggested, by all but a minority of interviewees, to be based on the strength of the social relations constituting the network. Lawyers all recognised the importance of cultivating relationships with their overseas colleagues that were not simply based on functional, transactional, necessity. Instead, they suggested relationships had to be developed over extended periods for non-transactional purposes (i.e. for cultivating 'non-contractual' social and professional relationships). As two lawyers commented:

"A lot of the work we do if cross border so we're constantly working with these guys. So without any deliberate intention to pick yourself a little group of buddies [and] you probably end up with these cross office networks. So there's a partner in New York that always uses me and I use him because we have this thing going on" (8).

"Working in the M\&A practice there are certain people working in that area and you get familiar with them and the more you work with them the more you get 
comfortable with them and can develop things. I think it's really important that you can develop these professional relationships that are more than just forced collaborations" (11).

It further emerged that these types of relationship are only successful when they are matured over time to create: trust-based bonds between individuals; a reciprocal desire to help one-another; and a belief in both the intentions of and advice given by a colleague. This mirrors the typologies of trust and its influence that others have described as being critical for the effective operation of relational organizational forms (Murphy, 2006). Lawyers argued, however, that creating such embedded relationships was not a simple process. In particular, success was a result of the way these individuals engaged in two principal practices, both of which help create trusting and reciprocal relationships between individuals and often rely on support from non-human actors.

First, regular virtual interaction that allows one-to-one communication between individuals was as being essential. This allows the maturation of network ties and all lawyers suggested that cementing inter-personal relationships and developing their social foundations began with one-to-one interactions by telephone. Here, as more than one interviewee put it, individuals could 'check each other out'; begin to develop an understanding of one-another's expertise and personal characteristics. By engaging in such interactions on a regular basis (daily with the most important 'network ties' when working together on a transaction and at minimum weekly) interpersonal networks began to 
develop and over time the socially embedding features described above emerged $^{10}$. As one lawyer described these embedded networks:

"So I talk to the same people probably two or three times a week at least and it's always the same people who ask me questions and it's always them I call when I've got a question. It just works best that way because it's based on a social bond, some kind of solid relationship" (21).

Of course, such activities are also supplemented by regular email interactions and, as noted above, the sharing of useful case studies. These (non-human) technologies further reinforce the relationships formed through the telephone conversations that act as the backbone of embedded relationships because of the spontaneous discussion they enable. This line of enquiry also revealed an important role for a second practice that further advances the embedding process.

Second, then, occasional face-to-face encounters were unanimously highlighted by lawyers as playing a pivotal role in further ensuring the knowledge producing networks are embedded in the strongest and most effective social spaces possible. For the lawyers interviewed, business travel was a fundamental aspect of working for a global organization. Of those involved in this research, all

\footnotetext{
${ }^{10}$ Of course, not all relationships were successful. However, most lawyers argued it made good business sense to do everything possible to develop such relationships, even when there were apparent clashes in personal characteristics. Indeed, persevering to develop socially embedded relationships could help overcome some difficulties in interpersonal relationships between lawyers. This is discussed further in a latter section of the paper.
} 
travelled at least once a year whilst some (five interviewees) travelled over eight times a year and one travelled at least once a month (12 times a year). The frequency varied with seniority (see below) but in all cases business travel was recognised as an important activity for two reasons. First, it helps smooth crossborder transactions. Meeting clients and other members of a cross-border project team face-to-face allows the ironing out of the most complex issues in a transaction. Second, it further helps embed the relationships involved in knowledge production and circulation. Surprisingly, as much emphasis was placed on the second benefit as the first, with senior lawyers arguing that although the cost of business travel was not to be taken lightly, travel to 'network' with colleagues was a legitimate expense because of how it 'ties' the global network together. One partner likened it to turning contacts with overseas colleagues from 'pins in a map' to genuinely meaningful relationships.

Reflecting these ideas, all lawyers noted that their employers organized a range of opportunities to meet overseas colleagues. These included: global induction meetings where new recruits meet their overseas counterparts; global partner and practice group conferences (sometimes referred to as retreats); and away-day activities in overseas offices (used mostly to embed networks between European offices where day-trips were possible). As two lawyers described the benefits gained:

"We have a global partner conference, we have these other conferences with different practice groups and I suspect they are more successful because they are relaxed. You all work in the same practice area and have been in contact with one-another at some point, and that gives a degree of informality to it. Then, 
having dinner together, getting drunk together is the best way to develop it. I think that's probably the key, seeing people outside of the work context and really getting to know them, you know getting under their skins and letting them get under yours" (12).

“...our team is pretty good at trying to meet people, get out and about. Three of us went to [European place $\mathrm{x}$ ] last week just to meet them...My point of view is its brilliant because now if l've got a problem, l've pretty much met everybody from that office, and they'll be no problem, we'll get on, feel like we understand oneanother hopefully" (17, lawyer in London).

It was the combination of telephone mediated interactions and these face-to-face encounters that embedded the most successful knowledge producing and circulating networks. In this sense, it could be argued that telephone mediated interactions begin the process of 'thickening up' or 'embedding' relational networks in organizations whilst face-to-face contact finalises the social construction process. Initial contact by telephone allows a tentative social bond to be cultivated and provides an opportunity for reciprocity to develop and an awareness of shared interests to grow. Moreover, respect for one-another's work and professionalism can be nurtured when such interactions lead to mutual benefit, for example allowing a client's needs to be met more effectively. Faceto-face meetings then allow these tentative feelings and beliefs to be concretised. Whilst telephone interactions allowed an individual's character to be judged, all interviewees agreed that 'seeing them in the flesh' and 'the whites of their eyes' 
helped confirm these preliminary feelings and beliefs and reinforce the commitment they had to the relationship. These are commonly recognised benefits associated with embodied encounters (Urry, 2004). As one interviewee put it:

"We had some of our UK competition lawyers over from Brussels a few weeks ago for a training session and we never got to introduce each other to each other...And as it happens, as everyone started to work out who was who, they'd all had a lot to do with each other. The relationships were already partially built, they didn't start afresh once they had met face-to-face, they just consolidated it and made it stronger" (8).

\section{3) The affects of embeddedness}

In order to better understand the affects of the differentiated forms of relational network highlighted in figure 1 , it is useful to further examine the outcomes of such embedded and consolidated interpersonal relationships and relational action. This can be illustrated by the affects on some of the key difficulties that arise when globally stretched collaboration and learning takes place.

For just over half of the lawyers interviewed, the inter-personal networks that allow knowledge production and circulation had, in the past, been in some way affected by disagreements, conflicts of opinion or misunderstanding between parties. However, these individuals also described how strongly embedded relationships could overcome such difficulties and prevent such issues inhibiting 
stretched learning. A number of examples highlight the affect of embedded relational forms on such difficulties.

First, lawyers commented upon disagreements that emerged because of the differentiated behaviours and norms associated with legal practice throughout the World. In particular, interviewees regularly noted that corporate transactions are approached differently in US, UK and continental European jurisdictions respectively ${ }^{11}$. Without meaning to typify or excessively simplify the differences, the approaches can be summarised as follows: in the US lawyers respond to a problem by finding a solution; in the UK lawyers speculate about a likely solution; in continental Europe lawyers' state the legal position (in an academic style analysis of legal precedent and statues) and why that causes a problem. They do not suggest a solution. This can lead to difficulties and frustration when lawyers work together.

This issue can be understood through a range of extant studies, including those of professional cultures (Torstendahl, 1990) and the differences between civil and common law practice styles (Abel and Lewis, 1995). It also relates to the previous discussion of the emergence of 'mega law' from the USA. However, of most interest to our discussion here is the way such difficulties were overcome in embedded networks. Lawyers suggested it was possible to excuse such differences, tolerate them and prevent them from damaging the effectiveness of

${ }^{11}$ Continental European refers primarily to offices in the following cities in Western Europe: Amsterdam, Berlin, Brussels, Budapest, Frankfurt, Madrid, Milan, Pairs, Prague, Rome and Stockholm. Eastern European offices are now growing in importance and the same challenges are increasingly being experienced here too. 
inter-personal networks when relationships were embedded in the ways described above. As one noted:

"...the cultural thing means that integrating with these people is vital...So they do have different styles, you don't try and impose a single style on them because that would be wrong...it can make things hard at times though, they just don't work like we do, but you expect it and deal with it...It's a translation exercise, and its constantly developing. So there is if you like a willingness to accommodate cultural differences because if you know them you can understand and almost expect these differences and then cope with them" (12).

This highlights, then, the ways that processes of transnational embeddedness facilitate learning by creating trust and commitment but also by helping overcome the inevitable difficulties associated with interpersonal relationships in an economic context (Murphy, 2006). Such challenges are exaggerated in relationships stretched across space because of the unavoidable variations in approaches and priorities of individuals working in different markets and legal (jurisdictional) contexts, what Hess (2004) calls the 'societal embeddedness' of relational network forms. 'Transnational' embeddedness can help create tolerance and even forgiveness, something potentially absent in purely transaction network forms such as informal legal networks like The Interlex Group.

Table 3 provides further examples of the types of challenges embedded relational networks can overcome. All in all, it is clear that the creation of relational organizational space and time is a heterogeneous process that is negotiated differently across relational networks. The empirical material points to 
the importance of focussing upon the various actors and the way their actions construct space and time in which knowledge can be produced and 'flowed'.

[Insert table 3 here]

\section{5) Power, politics and inequality in relational networks}

Whilst the value of relational network forms was undisputed by lawyers, it was also clear that certain features of the networks could alter the dynamics of the relationships between actors. In particular, the networks were affected by: (a) different levels of inclusion in network constructing practices; and (b) uneven geographies of power constructed by actors and groups of actors in the networks. Both of these factors further highlight the need to complicate the analysis of global organizational networks so as to recognise the intricacies of the construction of relational spaces by key actors and the ordered preconditions and outcomes of relational interactions.

\section{1) Exclusivity in network forms}

Two factors were of particular significance in determining the value of relational networks and the level of inclusion of different individuals in network constructing practices. Both factors augured against the successful construction and exploitation of interpersonal networks by junior lawyers. First, junior lawyers (i.e. non-partners) were only able to develop networks with other non-partners. This in itself has value, but is of exponentially less value than talking to partners 
who are inevitably the most knowledgeable individuals in law firms (Hatsopoulos and Hatsopoulos, 1999) and have extensive and valuable 'grey hair' experience that can be learned from (Terret, 1998). Whilst partners would happily work with and advise associates in relation to a transaction, associates found it impossible to further these inter-personal networks and transform them into the type of socially embedded professional relationships essential for effective knowledge production and circulation. They suggested this could be explained by their inability to overcome the invisible walls created by the time honoured 'hierarchical' conditions common to law firms (Smigel, 1965). As two junior lawyers commented:

"I think culture does have to be changed to make partners realise that they have to share their knowledge with everyone not just the other partners... partners will have all the really valuable knowledge and won't pass it on to the likes of us...they don't want to share their knowledge because knowledge is all important...sometimes I think they want to walkout the door with all of it so no juniors can depose them. I guess the threat's not the same when it comes to sharing insights with someone who's already a partner" (7).

"Yeah I think they [well cultivated, socially embedded inter-personal networks] become more effective the more senior you get. It must be very helpful for partners to have people to draw on, and they're always asking favours of their partner colleagues. We can't do that, we just muddle on through as a group of associates" (14). 
This politics of exclusion was also created and reinforced by a second factor. Junior lawyers commented that business travel was more limited for them than for partners. They fell at the bottom end of the frequency range for travel. Those junior lawyers interviewed all travelled between one and three times a year. Most transactional travel (in relation to cross-border projects) was completed by partners because of their dominant role in client handling and legally complex situations. Other forms of business travel also occurred more frequently for partners with, for example, conferences/retreats occurring at least once a year. In contrast, junior lawyers were normally confined to an induction during their first year of employment, an overseas 'seat' as part of training and occasional (often bi-annual) attendance at practice group meetings. Consequently, junior lawyers were less able to develop the embedded networks needed to most effectively benefit from globally stretched learning. As one junior lawyer noted:

"...they're definitely attorneys who I have gotten to know through various crossborder transactions but my interactions with them are more on the basis of if I've got a question on a specific point I might give them a ring...most of these people I've never met. Its not uncommon for me go for a year or so without leaving New York but then on the other hand the partner next door can be in five different countries over the period of a month" (27).

A similar process is also partially responsible for the weakness of the knowledge networks interconnecting the South East Asian offices to those in Europe and 
North America (figure 1) ${ }^{12}$. Even for senior lawyers, travel to offices in South East Asia (or from South East Asia to Europe or North America) was infrequent due to the time and financial costs involved. This prohibits the embedding of relational networks in the same way as infrequent travel does for junior lawyers. It might also explain the important role of lawyer expatriation to South East Asian offices noted by Beaverstock (2004). As stretched embedded networks are weak, co-presence becomes important for the transfer of expertise.

This points, then, to the importance of recognising the patchiness of relational network forms and, in particular, the need to move beyond using mappings of relational networks as proxies of globalization and global interconnectivity. The existence of a corporate office network or 'production chain' alone is insufficient evidence to claim tight integration exists. Instead, the empirical material presented here would seem to suggest that an understanding of the socio-economic practices and the connections produced within the networks and the partial or selective forms of integration created by actors is important.

\section{2) 'Power' in embedded networks}

It also emerged from interviews that the networks of knowledge production are imbued with uneven geographies of power. This has an important structural

\footnotetext{
${ }^{12}$ An additional factor here is the starkly different legal context in South East Asia. Both the regulation of law firms and wider business systems are unlike US, UK or Continental European approaches (see for example Yeung, 2000). It is, therefore, more challenging to 'transfer' best practice (c.f. Gertler, 2003).
} 
affect on both the firms themselves but, also more widely, on the nature of 'global' corporate law. Of the key transnational legal PSFs listed in table 1, all emerged from primarily UK or US legal practices. This leads to the predominance of the type of US and UK 'mega-lawyering' described earlier in the paper. It emerged from interviews that global knowledge production and circulation networks are used to encourage, in particular, continental European offices and increasingly offices in the East of the continental block, to adopt mega-lawyering practices. This was a form of power that was predominantly (though not exclusively) exercised by partners in the New York offices of both US and UK transnational legal PSFs. The following quotes exemplify the way the knowledge producing networks are used to catalyse the development of corporate legal practice in Eastern Europe:

"In a broader sense the US standards of disclosure as regards security law has had a significant impact on how the rest of the world works, and especially mainland Europe, and so often its useful to get some idea [of] how its done....and we can provide that to other offices, to our colleagues" (25, partner based in New York).

"...we group ourselves globally by the practice of law that we do rather than locally and we talk every week about a legal issue but in each jurisdiction and how that's then treated in each jurisdiction...And its particularly helpful to the offices that are just joining the EU...so we're talking to lot of country's to see if we can sort them out, what's going to happen and how they should practice now. So again, sharing of experience on a cross-jurisdictional basis to develop their practice" (18, partner based in London). 
The construction of this power is possible, firstly, because of the concentration of travel within Europe by lawyers from the USA and UK for interpersonal networks construction. For example, interviewees in New York suggested that for every one trip to South East Asia they would make at least three trips to Europe. Consequently, the embedded networks are 'strong' (see figure 1) and can be effectively used to reproduce the Cravath model of practice.

Secondly, this power is also constructed and reinforced by the way partners, in particular in the New York offices of the firms studied, depict and portray the continental European offices. A form of rhetoric has developed over time that constructs these offices as needing the 'assistance' of, in particular, the New York office to deal with the complexities of global corporate transactions. Consequently, Continental European offices are seen as being the benefactors of such assistance in that their legal practices and their ability to compete in a global marketplace has developed. The recent transition of Continental European jurisdictions towards a more corporate-orientated form of legal practice is undoubtedly both the justification for and outcome of this process (Morgan and Quack, 2005). The way two partners working in the New York offices of transnational law firms described continental European offices exemplifies this point:

"...by and large it's [knowledge circulation and production] traffic that goes [across the networks] from us to them and not to us from them. So what most people are interested in is the US aspects of or how you do something...So the person handing out the knowledge [in the US] might hand out five units and get 
one unit back, and I think that's to be expected... If I was in Madrid having this conversation I would say its incredibly important because I need these guys to help me to do what I do, and I think that's true of most offices around the world" (23).

"When I started out if you were buying assets in Italy you would have a five page contract...it was simplistic, that's how people would do business...And I don't know if its because financing has become globalised, or people in Europe and Asia have kind of scratched their heads because American companies buying businesses weren't going to have a simplistic five page contract and wanted to work in our way, but these countries have really moved forward since they listened to our advice and ideas" (29).

These 'structural' preconditions in transnational law firms, whereby the London and New York offices are seen as leaders of legal practice, results in interesting forms of power in the relational networks constructed. It creates networks that are used to influence the way law is practiced in other jurisdictions so as to smooth the completion of global transactions. The emergence of such a transnational influence over legal practice challenges what has often been seen as a national sphere of control in which national professional regulators and legal associations have control over the practice of nationally registered lawyers. However as Morgan and Quack (2005) note in relation to law, and others have described for finance and other industries (Bathelt and Gertler 2005; Morgan, 2001; Wójcik, 2006), national institutional and regulatory systems are increasingly influenced by transnational forces as a result of the activities of 
TNCs. In this case it means that the global knowledge production and circulation networks of transnational law firms are often conduits for the transferral, or at least the overseas re-translation, of principally US legal practice. Consequently, the advice provided to clients and the structures used for cross-border mergers, acquisitions, re-financings and other corporate transformations often takes a distinctly US or UK style (The Economist, 1996; Trubek et al. 1994). When coupled with the corporate 'socialization' processes associated with work in large PSFs which aim to ensure all employees deliver uniform and standard services across the firm's network (see Covaleski et al. 1998), this has significant structural outcomes for the nature of corporate law ${ }^{13}$. Indeed, it could be argued that the globally stretched knowledge networks are partially responsible for the 'Americanization' of corporate legal practice others have noted (Trubek et al. 1994; Flood, 1995) and that, as Morgan (2006) suggests, corporate lawyers in transnatonal law firms are the forward-party of US capitalism, clearing the legal way for TNCs to operate using US standards that are increasingly seen as capitalist 'best practice' throughout the world. This, then, might explain China and other countries reticence to fully open their legal markets to transnational firms.

\footnotetext{
${ }^{13}$ All of the law firms studied in this research operated some form of 'global training' events, in particular for newly recruited lawyers. Whilst the firms did not have the type of 'global academy' often associated with accountancy firms such as PriceWaterhouseCoopers, they did use global gatherings as a way of training new recruits to deliver a 'firm x' style service. Especially for US originating firms but also for those from the UK, this was a mega-law style service.
} 
In this sense, the relational constitution of power is related to both 'structural' preconditions and the creation of new structures in the global space economy. Sheppard (2002) highlights how global networks often draw on and recreate relationships of dependence in the global economy. The analysis provided here goes further, however, and also reveals the way relational networks can produce new forms of power laden interdependencies, creating new positions of inequality and economic muscle. As a transnational legal realm potentially begins to emerge (Flood, 1995, 1996; Trubek et al, 1994), US and to a lesser extent UK firms have used the influence of their relational networks to create and recreate a position of power for themselves. Whilst this has been implicit in the arguments put forward previously about relational networks (e.g. Dicken et al. 2001), to date there has been a dearth of empirical analysis of such issues (but see Johns, 2006).

We can push this analysis even further. Geographers have been reminded in recent times, above all by the contributions of John Allen $(2002 ; 2003)$, that discussions of power need to take a more critical stance. For Allen, power takes multiple forms, something determined by the way it is exercised ${ }^{14}$. He argues it is, therefore, important to begin by recognising the mode of power employed

\footnotetext{
${ }^{14}$ Allen (2003) distinguishes between authority, coercion, domination, inducement, manipulation and seduction as different forms of power. Each it exercised through relationships that construct power in unique ways, for example using different combinations of presence to draw individuals into line and constrain actions, concealment to hide intentions but manipulate individuals and numerous other forms of strategic behaviour.
} 
before exploring the construction of powerful relations between actors and the actions involved in this process.

According to Allen's typology of the different forms of power, the power identified in the global networks of knowledge production in this paper is a form of domination. Allen $(2003,28)$ suggests that where domination occurs it "may involve relationships close at hand or across vast distances, but in either case the imposition of a form of conduct according to a set of particular interests is characteristic". This is subtly different to authority. Domination is a form of power accepted out of resignation to the powerful influence of the other party. Authority is power conceded because of recognition of the other parties' legitimate claim to power and influence. The way the power is constructed in the networks studied here reveals why such a distinction is important.

Lawyers in New York acknowledged that the relationship between offices is one where continental European lawyers are resigned to the need to learn from and retranslate the ideas and practices produced and circulated by, in particular, the New York office. Both client demands for 'megalaw' style legal services and the relative financial, and therefore managerial, dominance of New York offices in transnational law firms' networks' create such a situation ${ }^{15}$. In particular, the balance sheets detailing revenues and profits for each office that

\footnotetext{
${ }^{15}$ An example of this financial muscle can be seen in the differences in turnover between two offices of one global law firm. In 2002 Shearman Sterling's New York office has a turnover of in excess of $£ 209 \mathrm{~m}$ whilst the Paris office has a turnover of just over £39.5m (The Lawyer, 2003). This is representative of the differentials between New York and continental European offices in all of the law firms studied.
} 
are circulated at regular intervals for all partners to peruse result in power-imbued relations between offices with the nature of the relationship influenced by the level of profit generated by each office. Unsurprisingly, the most profitable offices are also the most influential offices, even when these are not the 'home country' offices of the firm. Consequently lawyers in New York mobilise both the need of their European counterparts to provide clients with a US style service, and the high levels of financial muscle held by the New York offices, as resources to 'exercise' power.

This suggests, then, that approaching 'power' as a socially constructed and relational formation might lead us further towards understanding the power structures affecting the global space economy. It reveals the importance of understanding the interplay between extant ordering in relational networks and the actions and reactions of key actors in order to fully conceptualise the geographies of globalization. This requires the type of micro-level investigation

presented here with the actors, not just the network structures, being the focus of our attention. It also further reveals the value of viewing relational networks as social constructions. This allows us to fully explore the power geometries produced through social practice and heterogeneous social relationships.

\section{6) Discussion and conclusions}

There has been much debate about the most effective way to conceptualise globalized economic activities with general agreement that analysis should focus upon the intensity of connections and relations between 
actors and places (Amin, 2002; Dicken et al. 2001; Peck and Yeung, 2003). Indeed, the growing belief that a topographic imaginary is needed to effectively conceptualise the geographies of global activity are supported in many ways by this paper. However, the findings also point to the inherent sophistication of such processes and the need to fully understand both the forms of social practice and embeddedness constituting and influencing such networks. Two main points have been made here.

First, the paper offers an empirical exposition of the socially constructed nature of global economic activities and relational networks. Whilst Jones (2005), Yeung (2004) and others have pointed to the importance of such an approach, there has been a dearth of the type of fine-grained analysis offered here of such processes. In this study, the knowledge production networks of legal PSFs have been unpacked and shown to be socially formed and embedded constructions, created through intricately managed interpersonal relationships. Importantly, the empirical material also highlights the importance of studying the various actors and their intentional strategies for enhancing and exploiting, relational networks. For example, the discovery of the synergistic use of social interaction mediated by virtual and travel enabling technologies to construct and embed relational networks highlights the need to view corporate networks as delicate spaces of human and non-human practice and engagement.

Second, the paper also makes a significant contribution in terms of further developing understanding of the way power affects relational networks activities. It has been shown that global relational networks operate in a recursive state, 
both being guided by extant ordering and socio-economic conditions but also reinforcing and reconstituting them. The example of attempts to reconfigure legal practice in Europe through a form of 'Americanization' shows how positions of power in the global economy can be reproduced and entrenched through relational networks (Allen, 2003; Sheppard, 2002). This reinforces the value of focussing upon the ongoing practices of actors within such network and their effects on the operation of relational economic activities and the global economy more widely.

Consequently, there seems to be two significant areas of future research that can emerge from this starting point. First, it is clear that, for economic geographers, there is still work to be done to develop our understanding of the geographies and practices of knowledge production. The findings presented here tie in with Allen's (2002) call for more sensitive and elegant analyses of both the way knowledge is produced and its spatialities but also suggests that beyond discussions of the geographies of tacit knowledge (Amin and Cohendet, 2004; Gertler, 2003), there are important debates to be held about the spatial politics and power of networks of knowledge production and 'flow' in the global space economy. Approaching such questions using the type of subtle analysis proposed here might help in this cause.

Second, the research has provided detailed evidence to support calls for the continued explosion of the black box used to represent firms (Jones, 2005; Taylor and Asheim, 2001; Yeung, 2001). Specifically, the paper has identified the need to hone in on the individual actors in relational networks processes, 
their positionality and intentionality, and the affects of this on the ordering of relational networks themselves and wider economic arenas. Together, such approaches might further help us demystify the affects of relational organizational forms on the geographies of economic activity.

\section{Acknowledgements}

The comments provided by Jon Beaverstock on earlier draft of this paper were most helpful, as were the comments of two of the anonymous referees who further sharpened the focus of the paper. Simon Chew produced the artwork for figure 1. Of course, I remain responsible for all of the ideas presented here and any errors that remain. 


\section{References}

Abel, R L Lewis, P S C. 1995. Lawyers in society: An overview. University of California Press, London.

Allen, J. 2004. The whereabouts of power: politics, government and space. Geografiska Annaler B: Human Geography 86B 1, 19-32

Allen, J. 2003. Lost Geographies of power. Blackwell, Oxford,

Allen, J. 2002. Living on thin abstractions: more power/economic knowledge.

Environment and Planning A 34 451-466

Amin, A. 2002. Spatialities of globalization. Environment and Planning A 34 385-399

Amin, A Cohendet, P. 2004. Architectures of knowledge: Firms capabilities and communities. Oxford University Press, Oxford,

Amin, A Cohendet, P. 1999. Learning and adaptation in decentralised business networks. Environment and Planning D: Society and Space 17 87-104

Bartlett, C Ghoshal, S. 1998. Managing across borders: the transnational solution. Random House, London,

Bathelt, H Gertler, M. 2005. The German variety of capitalism: forces and dynamics of evolutionary change. Economic Geography 81 1, 1-9

Bathelt, H Glucker, J. 2003. Towards a relational economic geography. Journal of economic geography 3 117-144

Beaverstock, J V. 2004. 'Managing across borders': knowledge management and expatriation in professional legal service firms. Journal of economic geography 42 , $157-179$

Beaverstock, J V Smith, R Taylor, P J. 1999. The long arm of the law: London's law firms in a globalising world economy. Environment and Planning A 13 1857-1876 
Blanc, H Sierra, C. 1999. The internationalisation of R\& D by multinationals: a trade-off between external and internal proximity. Cambridge Journal of Economics 23 187-206

Boggs, J S Rantisi, N. 2003. The relational turn in economic geography. Journal of economic geography 3 109-116

Brock, D M Powell, M J Hinings, C R. 1999. Restructuring the professional organization. Corporates, cobwebs and cowboys. Routledge, London and New York, 215-229

Bunnel, T Coe, N. 2001. Spaces and scales of innovation. Progress in Human Geography 25 4, 569-589

Covaleski, M A Dirsmith, M W Heian, J B Samuel, S. 1998. The calculated and the avowed: techniques of discipline and struggle over identity in Big Six public accounting firms. Administrative Science Quarterly 43 293-327.

Currah, A Wrigley, N. 2004. Networks of organizational learning and adaptation in retail TNCs. Global Networks 4 1, 1-23

Daniels, P W. 1993. Service industries in the world economy. Blackwell, Oxford Department for Trade and Industry. 1998. Our competitive future building the knowledge driven economy - government White paper. Department for Trade and Industry, London

Dicken, P Kelly, P F Olds, K Yeung, H W-C. 2001. Chains and network, territories and scales: towards a relational framework for analysing the global economy. Global Networks 12, 89-112

Economist The. 1996. The globalisation of corporate law. The Economist November 1996 109-112

Faulconbridge, JR. 2006. Stretching tacit knowledge beyond a local fix? Global spaces of learning in advertising professional service firms' Journal of Economic Geography 6 517-540. 
Faulconbridge, J R. 2007. Exploring the role of professional associations in collective learning in London and New YorkXs advertising and law professional service firm clusters. Environment and Planning A 39

Faulconbridge, J R. Forthcoming. London and New YorkXs advertising and law clusters and their networks of learning: relational analyses with a politics of scale? Urban Studies.

Ferner, A Edwards, P Sisson, K. 1995. Coming unstuck? In search of the 'corporate glue' in an international professional service firm. Human resource management 343 , 343-361

Flood, J. 1995. The cultures of globalization: professional restructuring for the international market. In Dezalay, Y, D Sugarman (Eds). Professional competition and professional power. Lawyers, accountants and the social construction of markets. Routledge, London, 139-169.

Flood, J. 1996. Megalawyering in the global order: the cultural, social and economic transformation of global legal practice. International journal of the legal profession 3 $1 / 2,169-214$

Gertler, M. 2003. Tacit knowledge and the economic geography of context, or the undefinable tacitness of being (there). Journal of economic geography 3 75-99 Glaser, B Strauss, A. 1967. The discovery of grounded theory. Aldine, Chicago, Grabher, G. 2002. Cool projects, boring institutions: temporary collaboration in social context. Regional Studies 36 3, 205-214

Hatsopoulos, N G Hatsopoulos, G. 1999. The role of tacit knowledge in management. In Sternberg, R J, J Horvath (Eds). The role of tacit knowledge in management. Lawrence Elbraum Associates, London, Number of 
Herod, A. 1999. Reflections on interviewing foreign elites: praxis, positionality, validity and the cult of the insider. Geoforum 30 313-327

Hess, M. 2004. Spatial relationships? Towards a reconceptualization of embeddedness. Progress in Human Geography 28 2, 165-186.

Johns, J. 2006. Video games production networks: value capture, power relations and embeddedness. Journal of Economic Geography 6 2, 151-180

Jones, A. 2005. Truly global corporations? Theorizing organizational globalisation in advanced business-services. Journal of economic geography 5 177-200

Lawyer The. 2006. The global 100 (2006 edition). The Lawyer, London

Lawyer, The. 2004. The global 100 (2004 edition). The Lawyer, London

Lawyer, The. 2003. The global 100 (2003 edition). The Lawyer, London

Leadbeater, C. 1999. Living on thin air: the new economy. Viking, London,

Lowendahl, B. 2000. The globalisation of professional business service firms. Fad or genuine source of competitive advantage? In Ahorni, Y, L Nachum (Eds).

Globalization of services. Some implications for theory and practice. Routledge, London, Number of 146-162

MacDonald, K M. 1995. The sociology of the professions. Sage, London, Morgan, G. 2001. Transnational communities and business systems. Global Networks 1 113-130

Morgan, G. 2006. Transnational actors, transnational institutions, transnational spaces: the role of law firms in the internationalization of competition regulation. In Djelic, M-L, K Sahlin-Andersson (Eds). Transnational governance. Institutional dynamics of regulation. Cambridge University Press, Cambridge, 139-160.

Morgan, G Quack, S. 2005. Institutional legacies and firm dynamics: the growth and internationalization of UK and German law firms. Organization Studies 26 12, 17651785 
Morris, C Empson, L. 1998. Organisation and Expertise: An Exploration of Knowledge Bases and the Management and Consulting Firms. Accounting organizations and society $235 / 6,609-624$

Murphy, J T. 2006. Building trust in economic space. Progress in Human Geography 30 $4,427-450$

Nelson, R L Trubek, D M. 1992. Introduction. New problems and new paradigms in studies of the legal profession. In Nelson, B L, D M Trubek, R L Solomon (Eds). Introduction. New problems and new paradigms in studies of the legal profession. Cornell University Press, London, 1-27

Nohria, N Ghoshal, S. 1997. The differentiated network. Jossey Bass, San Francisco, OECD. 2000. Knowledge management in the learning economy. OECD, Paris Peck, J Yeung, H W-C. 2003. Remaking the global economy. Sage, London. Schoenberger, E. 1997. The cultural crisis of the firm. Blackwell, Oxford, Schoenberger, E. 1991. The corporate interview as a research method in economic geography. The Professional Geographer 43 2, 180-189

Sheppard, E. 2002. The spaces and times of globalization: place, scale, networks and positionality. Economic geography 78 307-330

Skymre, D J. 1999. Knowledge networking. Creating the collaborative enterprise. Butterworth Heinemann, Oxford, Smigel, E O. 1965. The Wall Street lawyer. Professional organization? Free Press, Glencoe,

Spar, D L. 1997. Lawyers abroad: the internationalization of legal practice. California management review 39 3, 8-28

Sturgeon, T J. 2003. What really goes on in Silicon Valley? Spatial clustering and dispersal in modular production networks. Journal of economic geography 3 199-215 
Terret, A. 1998. Knowledge management and the law firm. Journal of knowledge management 2 1, 67-76

Torstendahl, T Burrage, M. 1990. The formation of professions: knowledge, state and strategy. Sage, New York

Trubek, D M Dezalay, Y Buchanan R Davis, J R. 1994. Global restructuring and the law: studies of the internationalization of legal fields and the creation of transnational arenas. Case Western Reserve law review 44 2, 407-498

UNCTAD. 2004. Trade and development aspects of professional services and regulatory frameworks. United Nations conference on trade and development, New York and Geneva

Urry, J. 2004. Connections. Environment and Planning D 22 27-37

Warf, B. 2001. Global dimensions of US legal services. The professional geographer 53 3, 398-406

Wenger, E McDermott, R Synder, W. 2000. Cultivating communities of practice. Harvard Business school press, Boston, MA,

Wójcik, D. 2006. Convergence in corporate governance: evidence from Europe and the challenge for economic geography. Journal of Economic Geography 6 639-660 Yeung, H W-C. 2005. Organizational space: a new frontier in international business strategy? Critical Perspectives on International Business 1 4, 219-240 Yeung, H W-C. 2004. Rethinking relational economic geography. Transactions of the Institute of British Geographers NS 30 1, 37-51

Yeung, H W-C. 2003. Practising new economic geographies. Annals of the Association of American Geographers 93 2, 442-462

Yeung, H W-C. 2001. Regulating the firm and sociocultural practices in industrial geography II. Progress in Human Geography 25 2, 293-302 
Yeung, H W-C. 2000. The dynamics of Asian business systems in a globalizing era.

Review of International Political Economy 7 3, 399-433 


\begin{tabular}{|c|c|c|c|c|}
\hline Firm & Nationality & $\begin{array}{c}\text { Global revenue }(£ m) \\
(2004)\end{array}$ & $\begin{array}{l}\text { Global employees: } \\
\text { partners (lawyers) }\end{array}$ & Global offices \\
\hline Clifford Chance & UK & 1030 & $575(2432)$ & 34 \\
\hline Linklaters & UK & 935 & $496(2072)$ & 31 \\
\hline $\begin{array}{l}\text { Skadden Arps Slate } \\
\text { Meagher \& Flom }\end{array}$ & USA & 885 & 377 (1699) & 23 \\
\hline $\begin{array}{c}\text { Freshfields Bruckhaus } \\
\text { Deringer }\end{array}$ & UK & 882 & $521(2013)$ & 28 \\
\hline Latham \& Watkins & USA & 776 & $514(1668)$ & 22 \\
\hline Allen \& Overy & UK & 736 & $424(1760)$ & 26 \\
\hline Baker \& McKenzie & USA & 743 & $601(2975)$ & 69 \\
\hline Jones Day & USA & 706 & $644(2178)$ & 18 \\
\hline White \& Case & USA & 574 & $353(1783)$ & 39 \\
\hline $\begin{array}{l}\text { Weil Gotshal \& } \\
\text { Manges }\end{array}$ & USA & 558 & $289(1129)$ & 16 \\
\hline
\end{tabular}

Table 1. They top 10 global law firms by number of overseas offices.

Source: The lawyer (2006) and Fieldwork. 
'Transactional' encounters as part of project-team work.
"Imagine a situation say where you're selling a billion pound company which is quite complicated and maybe has 500 subsidiaries around the world and all sorts of other bits and pieces...you probably need to have a group of people on your side from each jurisdiction who can advise you and you're in constant contact with them and get to know them really well" (6).

"We have twice monthly videoconferences on relevant topics and all practice groupings have comparable knowledge seminars.... We're also very informal, internet based contact using preset mailing lists to ask for help" (23)

"the most beneficial part of computer knowledge management systems is that it provides a dating service, they put people in touch with colleagues who can help them" (3)

“...if you're doing a deal in a particular industry sector and you want somebody from a particular office then your better going to someone within that sector...its just choosing the right man for the job. And that's done through the database of people and what they do" (18).

Table 2: Relational network formation practices.

Source: Fieldwork. 
The differences between common and civil law approaches to legal practice. The latter's codebased nature means lawyers define the problem rather than seek a solution. Embedded relationships allow appreciation of such differences and compromises to be reached.
"There are cultural differences, let me give you an example. If you came to me and said 'is that a pencil?' you would expect me to say 'no that's not a pencil it's a tea spoon'. If you went to a lawyer in Kazakhstan he'd probably say 'no'. So the AngloSaxon lawyer expects to go beyond the specific question and discuss what the issue is. That's a terrible over simplification and it's changed a great deal and we understand the difference but also increasingly find those lawyers we work with best realise that the expectation that you will get to the bottom of the real issue in London, New York, Sydney has to be met elsewhere. The expectation is problem solving rather than giving advice." (5).

"Trust is incredibly important so people trust that knowledge because otherwise they're not going to use it. It's a matter of building up trusts, building up relationships... That familiarity, that ability to judge the person, to judge whether they're taking the right decisions" (7).

"For example, there's the culture of the August holiday and in Italy, and unless you've got some very close contacts you'll get nothing during those months unless it's prearranged. That's no use if a deal suddenly comes up or you need support quickly. And you can deal with that when you've got these close ties, people will respond even if you call them on their mobile on the beach!" (18).

Table 3: The beneficial effects of embedded relational networks. Source: Fieldwork. 


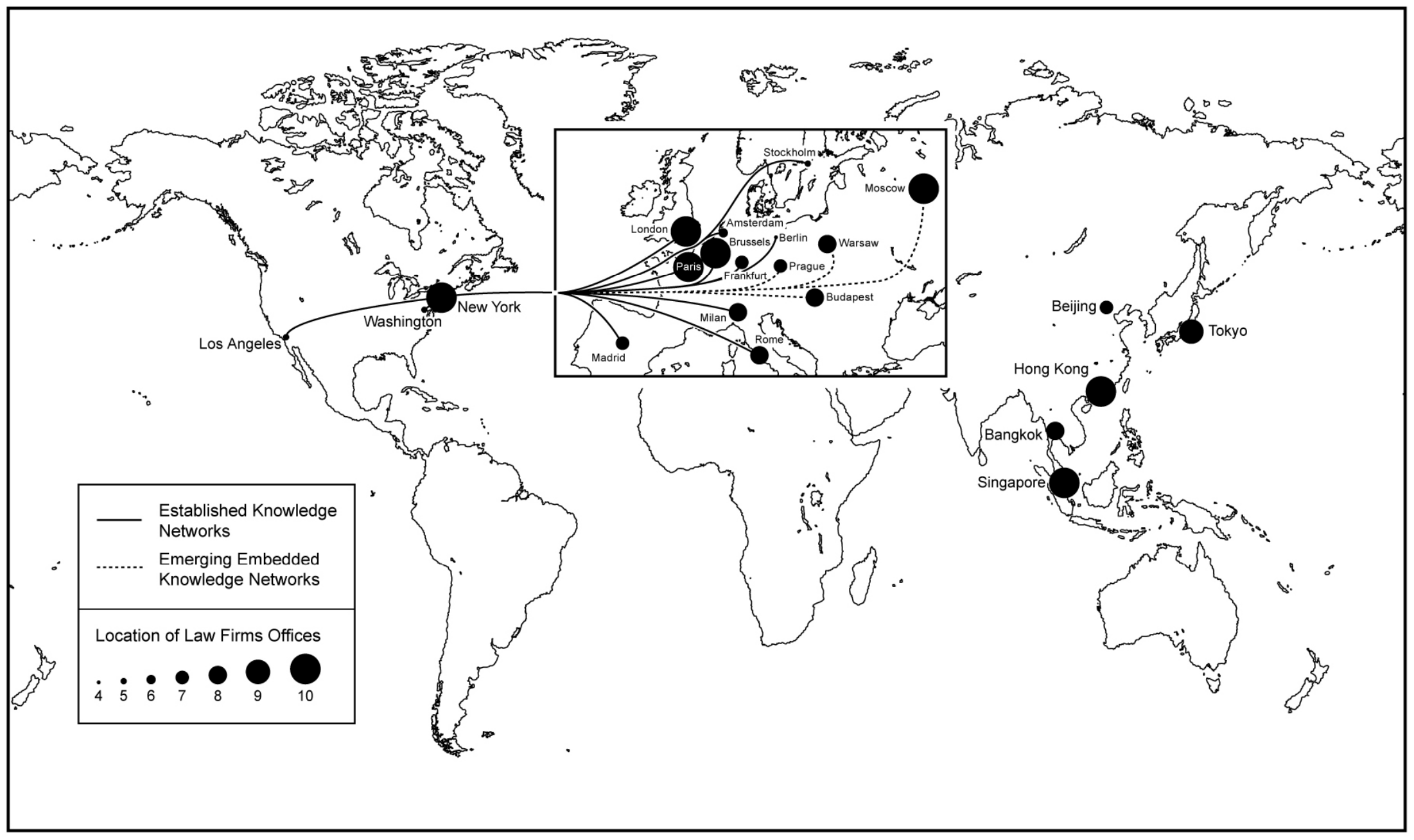

Figure 1. The geography of global legal PSFs offices and the knowledge networks stretched between them. Source: Fieldwork. 
